\title{
Response of 25 Hybrid Maize Against Salinity Stress and Their Performance in Coastal Area
}

\author{
MekoGustian, Rustikawati, Widodoand Catur Herison \\ Graduate Program of Agroecotechnology, Faculty of Agriculture, University ofBengkulu \\ Corresponding Author:tika_ngrh@yahoo.com
}

\begin{abstract}
Plant stress due to $\mathrm{NaCl}$ compound will have an impact on the reduction of plant growth and yield. Tolerant varieties are required to increase plant production in coastal areas since these areas are closely related to salinity. This study aimed to (1) determine the appropriate $\mathrm{NaCl}$ concentration for saline tolerance in maize stress selection, (2) determine the response of maize plant to salinity stress in nutrient culture, and (3) determine the response of new hybrid maize having adaptibility in coastal area. Two experiments were run from November 2017 until May 2018. The first experiment was conducted in greenhouse at Laboratory of Agronomy, Faculty of Agriculture University of Bengkulu to determine the tolerance response of 25 new hybrid maize to salinity in nutrient culture. The second experiment was conducted on coastal area in Beringin Raya Village, Muarabangkahulu District, Bengkulu City to determine the response of new hybrid maize having adaptibility in coastal area. The concentration of $\mathrm{NaCl}$ at which level the $\mathrm{LC}_{50}$ was determined was found to be in $150 \mathrm{mM}$. This concentration was then used to test the tolerance of 25 new hybrid maize to $\mathrm{NaCl}$ stress. The hybrids of CT18, CT19, CT22, CT25, CT31, СТ33, СT34, CT40, CT47, and CT50 showed good responses to the concentration treatment of $150 \mathrm{mMNaCl}$ based on plant fresh weight and shoot dry weight. The hybrids of CT17,CT19, and CT20 showed good adaptibility on coastal area based on the length of cob, diameter of cob, seed weight per cob, and cob weight per plant. Among those three hybrids, CT17 and CT20 resulted low fresh weight and low shoot dry weight. The factors other than $\mathrm{NaCl}$ in coastal area maybe affect better response. However, CT19 proved as a hybrid which was consistently in a good response to salinity stress both in nutrient culture and in coastal growing area.
\end{abstract}

Keywords: coastal, hybrid maize, $\mathrm{NaCl}$ stress, nutrient culture

Reference to this paper should be made as follows :

Gustian, M.,Rustikawati, Widodo and C. Herison. 2019. Response of 25 hybrid maize against salinity stress and their performance in Coastal Area. Agritropica: Journal of Agricultural Science. 2(2): 56-70. Doi: https://doi.org/10.31186/Jagritropica.2.2.56-70

\section{INTRODUCTION}

Maize (Zea mays L.) is a very important food crop because until now corn is a food substitute for rice for some Indonesian residents. Maize is classified as a plant species that has a very large genetic diversity and is able to produce new genotypes that can adapt to varied environments. Besides being used as food in line with the increase in science and technological advancements that corn plants are currently also being developed as energy producers, corn is one of the plants that produce bioethanol in quite large amounts (Dachlan et al., 2013). The area of maize plantations ranks second after rice when compared to other commodities. Based on data from the Central Statistics Agency (2019) corn imports in 2018 amounted to $73,722,813$ tons while corn imports in 2017 amounted to $51,749,614$ tons. It is estimated that corn imports will always increase with the addition of the population if not balanced with a real increase in national production.

The expansion of the planting area is an effort to increase national corn production. The land available for agriculture is mostly tidal areas (Sholihah and Saputro, 2016). Tidal land which is a land located in a coastal area. Coastal areas are areas that are very 
vulnerable to various conditions that can cause plant poisoning (Suwignyo et al., 2010). Coastal areas generally have sand textured so that the ability to retain water and nutrient absorption is very low and is influenced by salinity caused by sea water which can inhibit plant growth.

Salinity is a limitation of the increase in crop production because it can cause a decrease in crop yield caused by inhibition of absorption of nutrients and water by plants (Rosmayati et al., 2015). This situation causes the plant to become abnormal and a decrease in yield. Salinity is defined as the presence of dissolved salts in excessive concentrations in soil solutions. According to Follett et al., (1981) states that the effect of salinity on plants with 1:1 extraction levels of $0-0.45 \mathrm{dSm}-1$ (non-saline) can be neglected, 0.45-1.5 dSm-1 (low salinity) sensitive plants disturbed, 1.51-2.9 dSm-1 (moderate salinity) most plants are disturbed, 2.91$8.5 \mathrm{dSm}-1$ (high salinity) only undisturbed tolerant plants and $<8.5$ dSm-1 (very high salinity) only a few types of tolerant plants can grow.

Coastal land (coastal sand) is a marginal land with low water and nutrient storage capacity and sufficiently acidic $\mathrm{pH}$, causing poor plant growth due to disruption of $\mathrm{N}$ and $\mathrm{Ca}$ nutrient uptake and high $\mathrm{Al}, \mathrm{Fe}$, and $\mathrm{Mn}$ dissolution so as to poison plants and reduced availability of $\mathrm{Mo}, \mathrm{P}$ and $\mathrm{K}$. High salt solubility can inhibit water and nutrient uptake by plants as osmotic pressure increases (Tatipata and Jacob, 2013).

Corn is a plant that is sensitive to salinity, the salinity tolerant genotype is not currently available on the market. New salt-tolerant cultivars can be obtained through assembly of varieties.
New hybrids that have been assembled by Bengkulu University breeders from local elders have the potential to be adaptive to salinity because they are assembled from elders resulting from local mutations and bengkulu strains. The new hybrid selection for salinity can be carried out by nutrient culture methods and in the field. This study aims to (1) determine the appropriate $\mathrm{NaCl}$ concentration for maize selection against salinity tolerance, (2) determine the response of new hybrid maize to salinity stress through haradan culture (3) determine the response of new hybrid maize that is adaptive to coastal land.

\section{MATERIALS AND METHODS}

This research was conducted in November 2017 to May 2018 in the Greenhouse of Laboratory of Agronomy, Faculty of Agriculture, University of Bengkulu and on the coastal land in Beringin Raya Village, Muarabangkahulu District, Bengkulu City.

\section{Research design}

1. The response of new hybrid maize to salinity through nutrient culture

a. Determination of the level of $\mathrm{NaCl}$ concentration

Selection is set at a $50 \%$ endurance level (LC50). This experiment was carried out using a Completely Randomized Design (CRD) with one factor namely $\mathrm{NaCl}$ concentration consisting of 9 levels namely, 0 (without $\mathrm{NaCl}$ ), $60 \mathrm{mM}, 120 \mathrm{mM}, 180$ $\mathrm{mM}, 240 \mathrm{mM}, 300 \mathrm{mM}, 360 \mathrm{mM}, 420$ $\mathrm{mM}$ and $480 \mathrm{mM}$. The plant used was BISI 18 which was a drought tolerant criterion and one of the maize hybrids 
selected from several hybrids to be tested was CT 39. This experiment used the $\mathrm{AB}$ mix hydroponic nutrient solution.

b. Response of 25 new hybrid corns through nutrient culture

This experiment uses a completely randomized design with one factor consisting of 25 new hybrid corns namely CT16, CT17, CT18, CT19, CT20, CT21, СТ22, СТ23, СТ24, СТ25, СТ29, СТ31, СТ32, СТ33, СТ34, СТ39, СТ40, CT41, CT42, CT46, CT47, CT48, CT49, CT50 and CT51. Each experimental unit consisted of 3 plants. The concentration of $\mathrm{NaCl}$ solution used is LC50 based on the results of the experiment.

\section{Response of $\mathbf{2 5}$ new hybrid corns to coastal land}

The experiment was arranged with a Complete Randomized Block Design (RCBD). The treatment consisted of 25 new hybrid maize as mentioned in 3.2.1.b and a commercial hybrid, Bisi 18. Corn was planted in rows along $5 \mathrm{~m}$ with $80 \mathrm{~cm}$ spacing between rows and $20 \mathrm{~cm}$ spacing in rows. So we get 25 plants per unit experiment. Each treatment was repeated 3 times. Observations were made on 5 sample plants that were randomly selected.

\section{Research Stages}

1. The response of new hybrid maize to salinity through nutrient culture

a. Determination of the level of $\mathrm{NaCl}$ concentration

The stages of this research began with the preparation of a plastic tub that will be used as a planting medium. Plastic baskets measuring $20 \mathrm{~cm} \times 30 \mathrm{~cm}$ $x 10 \mathrm{~cm}$ are given a hole in the bottom that will be given an axis as a link between the tub containing nutrient solution and the tub containing sand as a planting medium. Sand that will be used as a planting medium is washed first and then put into a tub. Seed is germinated in a plastic tub that has been filled with sand media. For the preparation of the concentration series $\mathrm{NaCl}$ preparations were made in advance of $2000 \mathrm{mM} \mathrm{NaCl}$ stock. From this stock the series of treatment concentrations is made as shown in Table 1.

The hybrid test determining LC50 concentration used is Bisi 18 and CT 39. The test is carried out for 4 weeks or until the most sensitive plants have died.

Table 1. Concentrations of $\mathrm{NaCl}$ treatment

\begin{tabular}{|c|c|c|c|c|}
\hline \multirow{2}{*}{$\begin{array}{c}\text { Treatment } \\
\text { Concentration }(\mathrm{mM}) \\
\end{array}$} & \multicolumn{2}{|c|}{ Stock of AB Mix Solution (ml) } & \multirow{2}{*}{$\begin{array}{r}\text { Stock } \mathrm{NaCl} 2000 \\
\mathrm{mM}(\mathrm{ml}) \\
\end{array}$} & \multirow[t]{2}{*}{ Water $(\mathrm{ml})$} \\
\hline & $\bar{A}$ & $\mathrm{~B}$ & & \\
\hline 0 & 5 & 5 & 0 & 990 \\
\hline 60 & 5 & 5 & 30 & 960 \\
\hline 120 & 5 & 5 & 60 & 930 \\
\hline 180 & 5 & 5 & 90 & 900 \\
\hline 240 & 5 & 5 & 120 & 870 \\
\hline 300 & 5 & 5 & 150 & 840 \\
\hline 360 & 5 & 5 & 210 & 810 \\
\hline 420 & 5 & 5 & 210 & 780 \\
\hline 480 & 5 & 5 & 240 & 750 \\
\hline
\end{tabular}

The observation variable in the experiment was the determination of the level of $\mathrm{NaCl}$ concentration for the response of the new hybrid maize 
namely the plant fresh weight and canopy dry weight.

Data obtained from observations made graphs then determined the concentration of $50 \%$ pressure. Based on the graph obtained from these data, LC50 is determined. Based on Hoque et al., (2015) the main reference is on the canopy dry weight variable.

b. Response of 25 new hybrid corns through nutrient culture

The response of 25 new hybrid maize was carried out at the $\mathrm{NaCl}$ concentration results of experiment a with the same nutrient culture method. Observation variables for the response of 25 new hybrid corns were: plant height, number of leaves, root length, crown fresh weight, root fresh weight, crown dry weight and root dry weight. The observations of each variable were analyzed using analysis of variance with a $\mathrm{F}$ test of $5 \%$ level, if it was significantly different it would be continued by Scott and Knott's further tests. Based on Hoque et al., (2015) the main reference is on the dry weight variable.

\section{Response of $\mathbf{2 5}$ new hybrid corns to coastal land}

The study began with preparing the land by removing weeds and plant residues manually. Conducting soil treatment by hoeing and making 3 plots of experimental plots with a distance between $1 \mathrm{~m}$ repetitions.

Planting is done by inserting 1 corn seed into each planting hole with a distance between planting holes $80 \mathrm{~cm}$ x $20 \mathrm{~cm}$. Each planting hole is given 510 grains of Carbofuran 3\% to prevent interference from insects. Maintenance in this study includes watering, replanting, fertilizing, growing, controlling weeds and pest. Watering is done every morning and evening if the soil is dry or not rainy. Replanting is done at the age of the plant 1 week after planting (MST) which is done on plants that do not grow or die. Ferlilizer was barried in a hole about 10 $\mathrm{cm}$ apart from the plant with a dose of Urea fertilizer $150 \mathrm{~kg} / \mathrm{ha}$, SP36 200 $\mathrm{kg} / \mathrm{ha}$, and $\mathrm{KCl} 100 \mathrm{~kg} / \mathrm{ha}$. The second fertilization is done after the plants are 4 weeks after planting by giving 150 $\mathrm{kg} / \mathrm{ha}$ of urea fertilizer.

Soil planting is done when the plant is 4 MST at the same time as the second fertilization. Weed control is done if weeds start to grow at intervals of once a week starting from 1 MST by pulling or mechanically. Control of pests and diseases is done manually, mechanically and with pesticides when symptoms of an attack appear and in accordance with the symptoms of an attack that occurs.

Harvesting is done when the corn seeds are physiologically ripe. Harvest criteria such as corncobs are dry and there is a black layer at the end of the seeds. Corn kernels are pithy, shiny and if pressed with hand nails do not show pressure marks or not break. Observation variables at the selection stage of new hybrid corn fields that were tolerant of salinity, namely: plant height, stem diameter, ear length, ear diameter, seed weight per ear and ear weight per ear per plant. The data obtained were analyzed statistically using analysis of variance with a $\mathrm{F}$ test of $5 \%$ level, if there were significant differences in the treatments tested then the data was carried out further tests Scott and Knott using InfoStat software. 


\section{RESULTS AND DISCUSSION}

1. The response of new hybrid maize to salinity through nutrient culture

a). Determination of $\mathrm{NaCl}$

Concentration

Determination of $50 \%$ stress concentration of $\mathrm{NaCl}$ was carried out by nutrient culture experiments at several concentrations. Trial determination of $\mathrm{NaCl}$ concentration was carried out for 4 weeks. The results of tests carried out showed the plant was unable to grow at the age of 3 weeks after planting at a $\mathrm{NaCl}$ concentration starting at $300 \mathrm{mM}$ (Table 2). This shows that the higher the concentration of $\mathrm{NaCl}$, the more it will suppress the rate of plant growth. Saline stress affects plant growth because it can reduce the potential of groundwater which can cause plants poisoning $\mathrm{Na}^{+}$and $\mathrm{Cl}^{-}$(Tavakkoli et al., 2011).

The concentration of $480 \mathrm{mMNaCl}$ hybrid CT 39 no growth due to very high concentrations, while the Bisi 18 hybrid the higher the concentration of $\mathrm{NaCl}$ given, the lower the fresh weight value of plants (Table 3). Plant growth is inhibited due to the difficulty of the roots absorb water and nutrients that are influenced by $\mathrm{Na}$ and $\mathrm{Cl}$ ions so that it inhibits cell division and plant growth becomes stunted.

Table 2. The average plant growth of 3 replications at each $\mathrm{NaCl}$ concentration

\begin{tabular}{|c|c|c|c|c|c|c|c|c|c|}
\hline \multirow[t]{2}{*}{ Genotype } & \multirow{2}{*}{$\begin{array}{c}\text { Concentration } \\
\mathrm{NaCl}(\mathrm{mM})\end{array}$} & \multicolumn{4}{|c|}{$\begin{array}{l}\text { Number of plants } \\
\text { growing }\end{array}$} & \multicolumn{4}{|c|}{ Percent of plants grow } \\
\hline & & M1 & M2 & M3 & M4 & M1 & M2 & M3 & M4 \\
\hline Bisi 18 & 0 & 3.0 & 3.0 & 3.0 & 3.0 & 100.0 & 100.0 & 100.0 & 100.0 \\
\hline Bisi 18 & 60 & 3.0 & 3.0 & 3.0 & 3.0 & 100.0 & 100.0 & 100.0 & 100.0 \\
\hline Bisi 18 & 120 & 3.0 & 3.0 & 3.0 & 3.0 & 100.0 & 100.0 & 100.0 & 100.0 \\
\hline Bisi 18 & 180 & 3.0 & 3.0 & 3.0 & 3.0 & 100.0 & 100.0 & 100.0 & 100.0 \\
\hline Bisi 18 & 240 & 3.0 & 3.0 & 3.0 & 3.0 & 100.0 & 100.0 & 100.0 & 100.0 \\
\hline Bisi 18 & 300 & 3.0 & 3.0 & 0.0 & 0.0 & 100.0 & 100.0 & 0.0 & 0.0 \\
\hline Bisi 18 & 360 & 3.0 & 3.0 & 0.0 & 0.0 & 100.0 & 100.0 & 0.0 & 0.0 \\
\hline Bisi 18 & 420 & 3.0 & 0.0 & 0.0 & 0.0 & 100.0 & 0.0 & 0.0 & 0.0 \\
\hline Bisi 18 & 480 & 2.0 & 0.0 & 0.0 & 0.0 & 66.7 & 0.0 & 0.0 & 0.0 \\
\hline СТ 39 & 0 & 3.0 & 3.0 & 3.0 & 3.0 & 100.0 & 100.0 & 100.0 & 100.0 \\
\hline СТ 39 & 60 & 3.0 & 3.0 & 2.0 & 3.0 & 100.0 & 100.0 & 66.7 & 100.0 \\
\hline СТ 39 & 120 & 3.0 & 3.0 & 3.0 & 3.0 & 100.0 & 100.0 & 100.0 & 100.0 \\
\hline СТ 39 & 180 & 3.0 & 3.0 & 2.0 & 2.0 & 100.0 & 100.0 & 66.7 & 66.7 \\
\hline СТ 39 & 240 & 3.0 & 3.0 & 3.0 & 3.0 & 100.0 & 100.0 & 100.0 & 100.0 \\
\hline СТ 39 & 300 & 2.0 & 3.0 & 0.0 & 0.0 & 66.7 & 100.0 & 0.0 & 0.0 \\
\hline СТ 39 & 360 & 2.0 & 3.0 & 0.0 & 0.0 & 66.7 & 100.0 & 0.0 & 0.0 \\
\hline СТ 39 & 420 & 1.0 & 0.0 & 0.0 & 0.0 & 33.3 & 0.0 & 0.0 & 0.0 \\
\hline СТ 39 & 480 & 0.0 & 0.0 & 0.0 & 0.0 & 0.0 & 0.0 & 0.0 & 0.0 \\
\hline
\end{tabular}


Table 3. Fresh plant weights and shoot dry weight in two four-week-old hybrids

\begin{tabular}{ccccc}
\hline \multirow{2}{*}{$\begin{array}{c}\text { Concentration } \\
\mathrm{NaCl}(\mathrm{mM})\end{array}$} & $\begin{array}{c}\text { Fresh plant } \\
\text { weights }(\mathrm{g})\end{array}$ & $\begin{array}{c}\text { shoot dry } \\
\text { weight }(\mathrm{g})\end{array}$ & $\begin{array}{c}\text { Fresh plant } \\
\text { weights }(\mathrm{g})\end{array}$ & $\begin{array}{c}\text { shoot dry } \\
\text { weight }(\mathrm{g})\end{array}$ \\
\hline 0 & 40.09 & 3.18 & 42.57 & 3.52 \\
60 & 35.87 & 3.13 & 22.93 & 2.48 \\
120 & 25.19 & 2.28 & 26.21 & 2.86 \\
180 & 19.62 & 1.40 & 9.96 & 1.00 \\
240 & 9.18 & 0.86 & 11.42 & 1.30 \\
300 & 0.54 & 0.11 & 0.26 & 0.07 \\
360 & 0.40 & 0.09 & 0.15 & 0.00 \\
420 & 0.19 & 0.04 & 0.04 & 0.01 \\
480 & 0.11 & 0.03 & 0.00 & 0.00 \\
\hline
\end{tabular}

Fresh weights of plants in Bisi 18 hybrids from the test results of some $\mathrm{NaCl}$ concentrations formed a quadratic graph with the equation $\mathrm{y}=$ $0,0002 \times 2-0,1866 x+43,488$ so that LC50 was obtained at $150 \mathrm{mM} \mathrm{NaCl}$ concentration. The fresh weight graph of plants on CT 39 hybrids was more decreased compared to BISI 18 hybrids (Figure 1). CT 39 hybrid on the observed variables of plant fresh weight for LC50 determination was calculated from the equation $\mathrm{y}=$ $0,0002 x 2-0.1903 x+40.14$ so that the LC50 was at $112 \mathrm{mMNaCl}$ concentration.

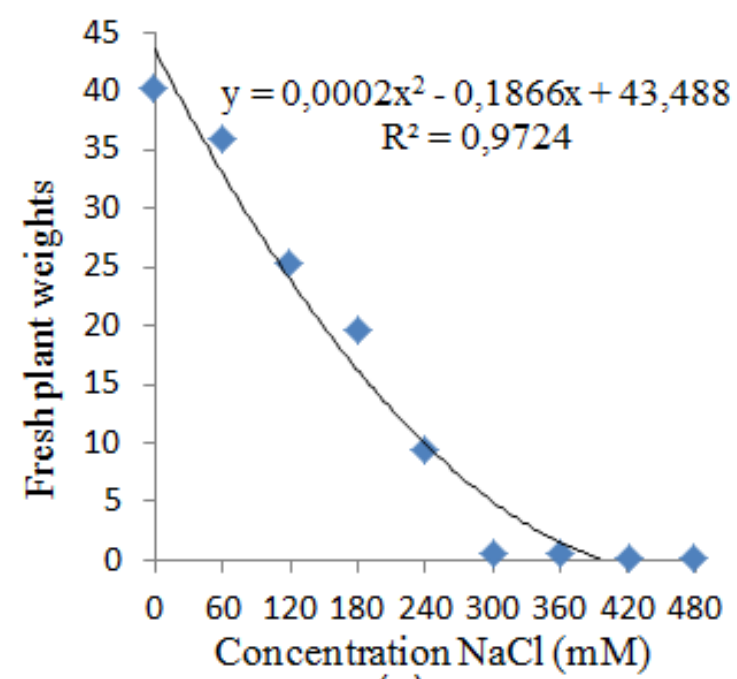

(a)
BISI 18 hybrid canopy dry weight four weeks after treatment with a concentration of $0 \mathrm{mM} \mathrm{NaCl}$ of 3.18 grams and the highest concentration of $480 \mathrm{mM} \mathrm{NaCl}$ of 0.03 grams, then the LC50 value is calculated from the graph with the equation $\mathrm{y}=2 \mathrm{E}-05 \times 2$ $0.0149 x+3,5758$ so that the LC50 value is at $149 \mathrm{mM} \mathrm{NaCl}$ concentration. While the canopy dry weight on CT 39 was formed quadratic graph with the equation $\mathrm{y}=1 \mathrm{E}-05 \mathrm{x} 2-0.0149 \mathrm{x}+3.6223$ so that LC50 was obtained at a concentration of $138 \mathrm{mM} \mathrm{NaCl}$ (Figure 2).

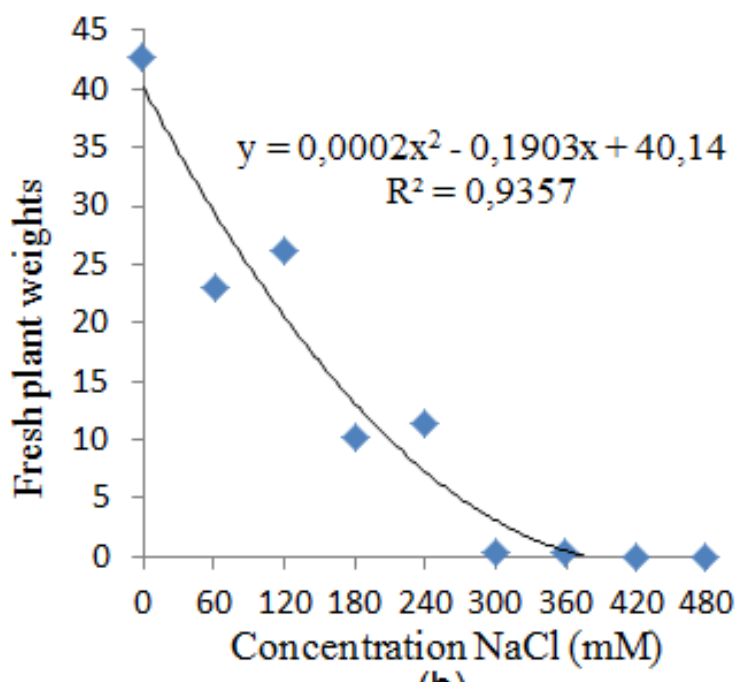

(b)

Figure 1. Graph of the relationship between plant fresh weight and $\mathrm{NaCl}$ concentration at (a) Bisi 18 and (b) CT 39. 


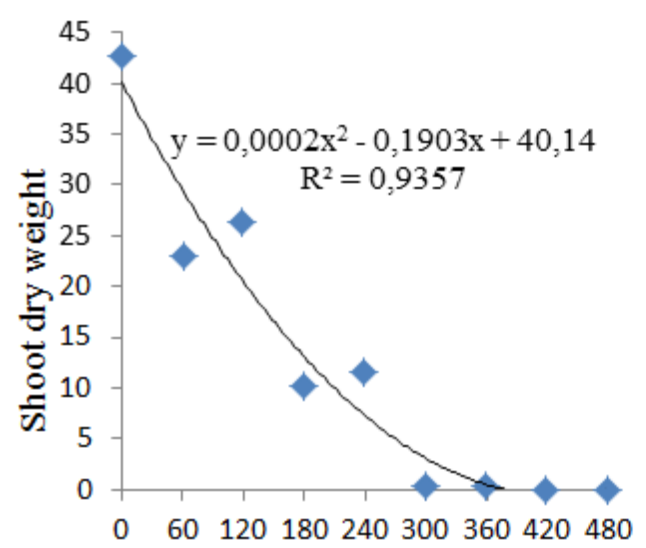

(a)

Concentration $\mathrm{NaCl}$

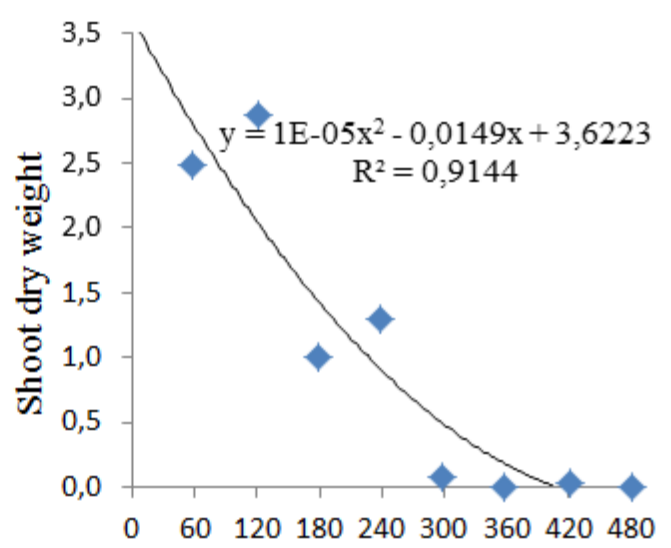

(b)

Concentration $\mathrm{NaCl}$

Figure 2. Graph of the relationship between shoot dry weight and $\mathrm{NaCl}$ concentration at (a) Bisi 18 and (b) CT 39

The response of plants to salinity can be seen decreasing in weight with the increase in concentration of $\mathrm{NaCl}$ (Dachlan et al., 2013). High salinity can cause an unbalanced respiration process and if the respiration process is greater than photosynthesis, the plant dry weight decreases (Latuharhary and Saputro 2017).

The crop fresh weight and crown dry weight graphs for the two hybrids tested did not have significantly different decreases. The reduced fresh weight of plants caused by the stress of $\mathrm{NaCl}$ thus affecting the absorption of water and nutrients, the dry weight of the crown also decreases. According to Dachlan et al., (2013) salt will affect the wet weight and dry weight of plants, Yustiningsih and Sila (2017) also stated that the plants given $\mathrm{NaCl}$ will experience a decrease in biomass. The test results of determining the concentration of $\mathrm{NaCl}$ stress pressure of $50 \%$ in two corn hybrids with LC50 is $150 \mathrm{mM}$ nutrient culture experiments because on CT 39 hybrids have LC50 values that are not much different from BISI 18 hybrids which is $150 \mathrm{mM}$ b). Analysis of variance using nutrient culture

The results of the analysis of variance on 25 new hybrid corns on $\mathrm{NaCl}$ administration showed that the observed variables of plant height, canopy fresh weight and canopy dry weight significantly affected between hybrids tested and root fresh weight had a significant effect (Table 4). Plants treated with $\mathrm{NaCl}$ salinity stress for 30 HST with different concentrations give a response to plant growth. Variable plant height, number of leaves, canopy fresh weight, root fresh weight, canopy dry weight and root dry weight have low KK values. This shows that the maize hybrid tested had a low difference in the observed variables. The higher the value of $\mathrm{KK}$, the wider the diversity of a plant's existing character. According to Effendy et al., (2018) the value of the coefficient of diversity is determined in the range of $0-100 \%$, a low $(0 \% \leq 25 \%)$, rather low $(25 \% \leq 50 \%)$, quite high $(50 \% \leq 75 \%)$, and high $(75 \% \leq 100 \%)$. 
Table 4. Results of analysis of variance and KK of corn plants through nutrient culture

\begin{tabular}{|c|c|c|}
\hline Variable & F Count & Coefficient of Diversity (\%) \\
\hline Plant length & $6.08 * *$ & 20.76 \\
\hline Leaf number & $1.39 \mathrm{~ns}$ & 21.22 \\
\hline Root length ${ }^{\mathrm{T}}$ & $1.51 \mathrm{~ns}$ & 27.34 \\
\hline Shoot fresh weight ${ }^{\mathrm{T}}$ & $2.69 * *$ & 22.25 \\
\hline Root fresh weight $\mathrm{T}$ & 1.79 * & 18.99 \\
\hline Shoot dry weight ${ }^{T}$ & $2.83 * *$ & 13.84 \\
\hline Root dry weight ${ }^{\mathrm{T}}$ & $1.42 \mathrm{~ns}$ & 9.93 \\
\hline
\end{tabular}

Remarks: ${ }^{*}=$ Significantly influential on the test level 5\%, ** Very significant effect on the test level $1 \%$, ns = No significant effect on the test level $5 \%, \mathrm{~T}=$ Data is transformed with $\sqrt{ } \mathrm{x}+1$

c). Response of 25 hybrid maize using nutrient culture.

The results of statistical analysis based on Scott and Knott's test of the resistance of corn plants to the administration of $\mathrm{NaCl}$ on plant height variables were tolerant plant groups namely CT 16, CT18, CT19, CT22, CT24, CT25, СТ31, СТ33, СТ34, СТ40, CT40, CT41, CT42, CT47 and CT50. CT 18 hybrid has the best response among several hybrids tested with a value of $34.53 \mathrm{~cm}$, whereas CT 46 is a hybrid that is sensitive to the administration of $\mathrm{NaCl}$ with a value of $11.83 \mathrm{~cm}$ (Table 5 . Decrease in plant height can be caused due to the limited availability of water and organic matter in the tissue due to the effect of salinity (Latuharhary and Saputro, 2017). Plant height is an indicator of plant growth and as a parameter used to see directly the influence of the environment or the treatment given to plants (Ekowati and Nasir, 2011). The effect of plant height is caused by the presence of osmotic stress which can make it difficult for plant roots to absorb water that is affected by the administration of $\mathrm{NaCl}$ (Dachlan et al., 2013) and Pranasari et al., (2012) stated that increasing the concentration of $\mathrm{NaCl}$ will cause plant height growth to be increasingly depressed.

The highest canopy fresh weight variable of the tested hybrids was 6.02 grams, namely CT 34 hybrid. $\mathrm{NaCl}$ stress gave effect to the canopy fresh weight because sensitive plants had difficulty in water absorption so that plant growth was inhibited. Asih et al., (2015) states that high salinity stress will reduce the division of cells in the roots. Whereas the highest fresh root weight variable was CT 50 grams but it was not significantly different from some of the hybrids tested and the lowest fresh root weight was CT 48 hybrid of 0.19 grams (Table 6). Measurement of plant biomass can be done by measuring fresh weight and dry weight, but biomass measurements more often use dry weight because the fresh weight of plants is strongly influenced by water content (Ekowati and Nasir 2011). Based on the canopy dry weight showed that there were several hybrid groups tested which were tolerant to the administration of $\mathrm{NaCl}$ at $150 \mathrm{mM}$ concentration, namely CT16, CT17, CT18, CT19, СТ22, СТ25, СТ31, СТ33, СТ34, CT40, CT40, CT47 and CT50, but the highest value the hybrids tested were 0.99 grams, namely CT 34 (Table 6). 
Table 5. Average growth of maize in some of the hybrids tested

\begin{tabular}{|c|c|c|c|}
\hline Genotype & Plant length $(\mathrm{cm})$ & Leaf number & Root length $(\mathrm{cm})$ \\
\hline CT 16 & $26.43 \quad \mathrm{a}$ & $2.87 \quad \mathrm{a}$ & $15.1 \quad \mathrm{a}$ \\
\hline СТ 17 & $22.07 \mathrm{~b}$ & $3.03 \mathrm{a}$ & $11.17 \mathrm{a}$ \\
\hline СТ 18 & 34.53 a & $2.93 \mathrm{a}$ & $16.1 \mathrm{a}$ \\
\hline CT 19 & 25.83 a & $3.1 \mathrm{a}$ & $11.23 \mathrm{a}$ \\
\hline CT 20 & $20.53 \mathrm{~b}$ & $2.7 \quad \mathrm{a}$ & $10.1 \mathrm{a}$ \\
\hline CT 21 & $17.07 \mathrm{~b}$ & $2.97 \mathrm{a}$ & $12.9 \mathrm{a}$ \\
\hline CT 22 & 29 a & $3.3 \mathrm{a}$ & $14.23 \mathrm{a}$ \\
\hline СТ 23 & $15.83 \mathrm{~b}$ & $3.03 \mathrm{a}$ & $8.7 \mathrm{a}$ \\
\hline CT 24 & $31.3 \mathrm{a}$ & $3.27 \mathrm{a}$ & $10.87 \mathrm{a}$ \\
\hline CT 25 & 26.73 a & $3.33 \mathrm{a}$ & $13.93 \mathrm{a}$ \\
\hline СТ 29 & $17.73 \mathrm{~b}$ & $3.33 \mathrm{a}$ & 10.43 a \\
\hline СТ 31 & $33.4 \quad \mathrm{a}$ & $3.33 \mathrm{a}$ & $16.03 \mathrm{a}$ \\
\hline СТ 32 & $14.1 \mathrm{~b}$ & $2.37 \mathrm{a}$ & $7.73 \mathrm{a}$ \\
\hline CT 33 & $30.3 \mathrm{a}$ & $3.7 \mathrm{a}$ & $13.2 \mathrm{a}$ \\
\hline СТ 34 & 32.3 a & $3.2 \mathrm{a}$ & $16.87 \mathrm{a}$ \\
\hline СТ 39 & $17.03 \mathrm{~b}$ & $3.2 \mathrm{a}$ & $6.2 \mathrm{a}$ \\
\hline CT 40 & $33.03 \mathrm{a}$ & $3.13 \mathrm{a}$ & $13.93 \mathrm{a}$ \\
\hline CT 41 & $23.77 \quad \mathrm{a}$ & $2.9 \quad \mathrm{a}$ & $8.17 \mathrm{a}$ \\
\hline CT 42 & $30.17 \quad \mathrm{a}$ & $3.07 \mathrm{a}$ & $8.63 \mathrm{a}$ \\
\hline CT 46 & $11.83 \mathrm{~b}$ & $2.13 \mathrm{a}$ & $5.77 \mathrm{a}$ \\
\hline СТ 47 & 29.23 a & $3.53 \mathrm{a}$ & $15.53 \mathrm{a}$ \\
\hline CT 48 & $12.9 \mathrm{~b}$ & $1.67 \mathrm{a}$ & $3.2 \mathrm{a}$ \\
\hline CT 49 & $20.37 \quad b$ & $3.03 \mathrm{a}$ & $11.03 \mathrm{a}$ \\
\hline СТ 50 & $31 \mathrm{a}$ & $3.33 \mathrm{a}$ & $16.4 \mathrm{a}$ \\
\hline СТ 51 & $18.47 \quad \mathrm{~b}$ & $3.27 \mathrm{a}$ & $13.1 \mathrm{a}$ \\
\hline
\end{tabular}

Remarks: the number of each column followed by the same letter shows no significant difference in the Scott and Knott test of 5\%

The results of Scott and Knott's analysis of several hybrids tested were found in hybrid groups that were tolerant of giving $\mathrm{NaCl}$ with a concentration of $150 \mathrm{mM}$. Based on canopy fresh weight and crown dry weight variables, namely CT18, CT19, CT22, СT25, СТ31, СТ33, СТ34, СТ40,
CT47, and CT50. However, the tolerant hybrid group showed that CT 34 was the best hybrid for $\mathrm{NaCl}$ salinity stress in nutrient culture based on observed variables such as root length, canopy fresh weight, canopy dry weight and root dry weight. 
Table 6. Average growth biomass of maize in some hybrids

\begin{tabular}{|c|c|c|c|c|c|c|c|c|}
\hline Genotype & $\begin{array}{l}\text { Shoot } \\
\text { weig }\end{array}$ & $\begin{array}{l}\text { fresh } \\
\text { ht (g) }\end{array}$ & $\begin{array}{l}\text { Root } \\
\text { weig }\end{array}$ & $\begin{array}{l}\text { fresh } \\
\text { t (g) }\end{array}$ & $\begin{array}{l}\text { Shoo } \\
\text { weigl }\end{array}$ & $\begin{array}{l}\text { dry } \\
t \text { (g) }\end{array}$ & $\begin{array}{r}\text { Roo } \\
\text { weig }\end{array}$ & $\begin{array}{l}\text { dry } \\
\text { ht (g) }\end{array}$ \\
\hline CT 16 & 1.98 & $\mathrm{~b}$ & 1.24 & $\mathrm{a}$ & 0.41 & $a$ & 0.11 & $\mathrm{a}$ \\
\hline CT 17 & 2.04 & $\mathrm{~b}$ & 0.80 & a & 0.41 & a & 0.17 & $\mathrm{a}$ \\
\hline CT 18 & 3.23 & $\mathrm{a}$ & 1.25 & a & 0.71 & a & 0.12 & $\mathrm{a}$ \\
\hline СТ 19 & 3.34 & $\mathrm{a}$ & 1.34 & a & 0.50 & a & 0.13 & $\mathrm{a}$ \\
\hline CТ 20 & 2.35 & $\mathrm{~b}$ & 0.80 & a & 0.36 & $\mathrm{~b}$ & 0.06 & $\mathrm{a}$ \\
\hline СТ 21 & 1.41 & $\mathrm{~b}$ & 0.73 & a & 0.22 & $\mathrm{~b}$ & 0.06 & $\mathrm{a}$ \\
\hline CТ 22 & 2.96 & $\mathrm{a}$ & 1.93 & a & 0.73 & $\mathrm{a}$ & 0.14 & $\mathrm{a}$ \\
\hline СТ 23 & 0.89 & b & 0.65 & a & 0.18 & b & 0.05 & $\mathrm{a}$ \\
\hline СТ 24 & 2.77 & $b$ & 1.23 & a & 0.48 & $b$ & 0.10 & $\mathrm{a}$ \\
\hline СТ 25 & 3.14 & $\mathrm{a}$ & 1.48 & a & 0.56 & $\mathrm{a}$ & 0.11 & $\mathrm{a}$ \\
\hline СТ 29 & 1.00 & b & 0.96 & a & 0.22 & $\mathrm{~b}$ & 0.10 & $\mathrm{a}$ \\
\hline СТ 31 & 3.13 & $\mathrm{a}$ & 0.99 & a & 0.59 & $\mathrm{a}$ & 0.10 & $\mathrm{a}$ \\
\hline СТ 32 & 1.67 & $\mathrm{~b}$ & 0.64 & a & 0.31 & b & 0.07 & $\mathrm{a}$ \\
\hline СТ 33 & 2.35 & $\mathrm{a}$ & 1.14 & a & 0.50 & $\mathrm{a}$ & 0.09 & $\mathrm{a}$ \\
\hline СТ 34 & 6.02 & $\mathrm{a}$ & 1.94 & a & 0.99 & $\mathrm{a}$ & 0.19 & $\mathrm{a}$ \\
\hline СТ 39 & 0.80 & $\mathrm{~b}$ & 0.41 & a & 0.17 & $\mathrm{~b}$ & 0.04 & $\mathrm{a}$ \\
\hline СТ 40 & 3.44 & $\mathrm{a}$ & 1.44 & a & 0.70 & $\mathrm{a}$ & 0.16 & $\mathrm{a}$ \\
\hline CT 41 & 1.95 & $\mathrm{~b}$ & 0.81 & a & 0.31 & $\mathrm{~b}$ & 0.08 & $\mathrm{a}$ \\
\hline CT 42 & 1.24 & $\mathrm{~b}$ & 0.64 & a & 0.25 & $\mathrm{~b}$ & 0.05 & $\mathrm{a}$ \\
\hline СТ 46 & 0.72 & $b$ & 0.53 & a & 0.14 & b & 0.15 & $\mathrm{a}$ \\
\hline CT 47 & 3.87 & $\mathrm{a}$ & 1.19 & a & 0.68 & $\mathrm{a}$ & 0.09 & $\mathrm{a}$ \\
\hline СТ 48 & 0.31 & $b$ & 0.19 & a & 0.05 & b & 0.01 & $\mathrm{a}$ \\
\hline СТ 49 & 1.81 & $b$ & 0.80 & a & 0.37 & b & 0.09 & $\mathrm{a}$ \\
\hline СТ 50 & 5.46 & $\mathrm{a}$ & 2.17 & $\mathrm{a}$ & 0.94 & $\mathrm{a}$ & 0.21 & $\mathrm{a}$ \\
\hline СТ 51 & 1.58 & $b$ & 1.02 & a & 0.29 & $b$ & 0.07 & a \\
\hline
\end{tabular}

Remarks: the number of each column followed by the same letter shows no significant difference in the Scott and Knott test of 5\%

\section{Response of $\mathbf{2 5}$ new hybrid corns to coastal land}

Based on the results of the analysis of variance shows that hybrid maize on coastal land has a very significant effect on variable plant height, cob length, ear diameter, seed weight per cob, and weight of cob per plot (Table 7). The variables of observation both vegetative and generative growth of all KK values are included in the low category because they have a coefficient value of $0-25 \%$. The low coefficient of diversity indicates that the variation within the genotype it self is small and it can be assumed that the genotype diversity among lines is low (Draseffi et al., 2015). 
Table 7. Analysis of variance and coefficient of diversity of maize on coastal land

\begin{tabular}{lcc}
\hline \multicolumn{1}{c}{ Variable } & F Count & Coefficient of Diversity (\%) \\
\hline Plant height & $6.22^{* *}$ & 6.67 \\
Stem diameter & $1.56 \mathrm{~ns}$ & 7.71 \\
Length of cob & $7.00^{* *}$ & 7.36 \\
Diameter of cob & $4,31^{* *}$ & 4.26 \\
Seed weight per cob & $4.16^{* *}$ & 14.07 \\
Cob weight per plant & $4.86^{* *}$ & 13.64 \\
\hline
\end{tabular}

Remarks: * = Significantly influential on the test level 5\%, ** Very significant effect on the test level 1\%, ns = No significant effect on the test level $5 \%$.

The results of the Scott and Knott BISI 18 (Table 8). Plant height is a test analysis showed that the highest variable that is often used to see the plant height variable was $211.0 \mathrm{~cm}$, good and bad growth of plants that are namely CT 46 and significantly influenced by environmental factors different from the comparative hybrid, (Ekowati and Nasir 2011).

Table 8. Average vegetative growth of new hybrid maize on coastal land

\begin{tabular}{|c|c|c|c|}
\hline Genotype & Plant height & Stem dia & neter \\
\hline BISI 18 & $168,6 \mathrm{c}$ & 16,7 & $\bar{a}$ \\
\hline CT 16 & $190,3 \mathrm{~b}$ & 17,5 & $\mathrm{a}$ \\
\hline СТ 17 & 182,9 b & 15,6 & $\mathrm{a}$ \\
\hline СТ 18 & 168,9 c & 15,3 & $\mathrm{a}$ \\
\hline СТ 19 & 183,6 b & 17,2 & a \\
\hline СТ 20 & 181,3 b & 16,0 & $\mathrm{a}$ \\
\hline СТ 21 & $175,9 \mathrm{~b}$ & 18,4 & $\mathrm{a}$ \\
\hline СТ 22 & $146,6 \mathrm{c}$ & 14,7 & $\mathrm{a}$ \\
\hline СТ 23 & $151,5 \quad \mathrm{c}$ & 17.0 & $\mathrm{a}$ \\
\hline СТ 24 & $146,5 \mathrm{c}$ & 15,8 & $\mathrm{a}$ \\
\hline СТ 25 & $159,7 \mathrm{c}$ & 15,9 & $\mathrm{a}$ \\
\hline СТ 29 & 179,6 b & 15,9 & $\mathrm{a}$ \\
\hline СТ 31 & $176,4 \quad b$ & 17,3 & $\mathrm{a}$ \\
\hline СТ 32 & $175,4 \quad b$ & 15,7 & $\mathrm{a}$ \\
\hline СТ 33 & $186,4 \quad b$ & 16,1 & $\mathrm{a}$ \\
\hline СТ 34 & 160,4 c & 16,3 & $\mathrm{a}$ \\
\hline СТ 39 & $161,0 \quad \mathrm{c}$ & 16,2 & $\mathrm{a}$ \\
\hline СТ 40 & 168,9 c & 15,8 & $\mathrm{a}$ \\
\hline СТ 41 & 147,9 c & 16,3 & a \\
\hline СТ 42 & $162,0 \quad \mathrm{c}$ & 16,3 & a \\
\hline СТ 46 & 211,0 a & 17,5 & $\mathrm{a}$ \\
\hline СТ 47 & 203,8 a & 18,3 & $\mathrm{a}$ \\
\hline СТ 48 & $178,2 \mathrm{~b}$ & 17,5 & $\mathrm{a}$ \\
\hline СТ 49 & $162, \mathrm{~A} \quad \mathrm{c}$ & 16,4 & $\mathrm{a}$ \\
\hline СТ 50 & 193,2 a & 15,8 & $\mathrm{a}$ \\
\hline СТ 51 & 180,8 b & 15,8 & $\mathrm{a}$ \\
\hline
\end{tabular}

Remarks: the number of each column followed by the same letter shows no significant difference in the Scott and Knott test of $5 \%$. 
High corn plants also do not determine that the plants are the best, even low plants do not indicate that the plants are not good. Low plants have the advantage of being resistant to lodging. A good plant height must also be supported by a large stem diameter in order to streng then the upright of the plant so that it is resistant to lodging.
The largest stem diameter of the hybrid tested was $18.4 \mathrm{~mm}$, namely CT 21 hybrid but was not significantly different from the other hybrids and comparison hybrids. In the stress condition of $\mathrm{NaCl}$, plants will divide the energy that should be used for stem diameter growth to overcome the salinity stress conditions (Kurniasari et al., 2010).

Table 9. Average generative growth of new hybrid maize on coastal land

\begin{tabular}{|c|c|c|c|c|}
\hline Genotype & $\begin{array}{c}\text { Length of } \\
\text { cob }\end{array}$ & $\begin{array}{c}\text { Diameter } \\
\text { of cob }\end{array}$ & $\begin{array}{c}\text { Seed weight } \\
\text { per cob }\end{array}$ & $\begin{array}{c}\text { Cob weight } \\
\text { per plant }\end{array}$ \\
\hline BISI 18 & $15,6 \quad b$ & $42,6 \quad a$ & 127,4 a & $177,1 \quad a$ \\
\hline CT 16 & 19,3 a & $39,6 \quad b$ & $76,0 \quad b$ & $112,7 \quad b$ \\
\hline CT 17 & 17,3 a & $42,6 \quad \mathrm{a}$ & 123,2 a & $152,7 \quad a$ \\
\hline CT 18 & $16,0 \quad b$ & $41,1 \quad b$ & $90,0 \quad b$ & $112,3 \mathrm{~b}$ \\
\hline СТ 19 & 17,0 a & 46,3 a & 128,0 a & $148,0 \quad a$ \\
\hline СТ 20 & 17,4 a & 41,9 a & 105,8 a & 140,9 a \\
\hline CT 21 & 17,3 a & $38,8 \quad b$ & $94,2 \quad b$ & 125,9 a \\
\hline CT 22 & $16,2 \mathrm{~b}$ & $39,9 \quad b$ & $92,1 \quad b$ & $106,8 \mathrm{~b}$ \\
\hline CT 23 & $12,7 \mathrm{~d}$ & $41,5 \quad b$ & $80,0 \quad b$ & $94,9 \quad b$ \\
\hline CT 24 & $15,2 \mathrm{~b}$ & $41,1 \quad b$ & $81,8 \quad b$ & $101,7 \quad b$ \\
\hline CT 25 & $13,5 \mathrm{~d}$ & $37,0 \quad b$ & $78,8 \quad b$ & $88,3 \quad b$ \\
\hline CT 29 & 16,8 a & $40,6 \quad b$ & 128,5 a & 133,1 a \\
\hline СТ 31 & $15,4 \quad b$ & $44,7 \quad$ a & 108,6 a & 142,9 a \\
\hline CT 32 & $14,9 \mathrm{c}$ & $44,7 \quad$ a & 104,6 a & 132,5 a \\
\hline СТ 33 & $14,7 \quad \mathrm{c}$ & $41,5 \quad b$ & 115,0 a & 136,3 a \\
\hline CT 34 & $15,5 \mathrm{~b}$ & $45,0 \quad a$ & $109,1 \quad a$ & 141,9 a \\
\hline СТ 39 & $13,0 \mathrm{~d}$ & $41,2 \quad b$ & $93,2 \quad b$ & $114,5 \quad b$ \\
\hline CT 40 & $12,5 \mathrm{~d}$ & $40,3 \quad b$ & $79,9 \quad b$ & $94,7 \quad b$ \\
\hline CT 41 & $13,3 \mathrm{~d}$ & $38,9 \quad b$ & $76,4 \quad b$ & $92,1 \quad b$ \\
\hline CT 42 & $12,7 \mathrm{~d}$ & $43,2 \quad a$ & $97,3 \quad b$ & 122,5 a \\
\hline CT 46 & $15,4 \quad b$ & 42,3 a & $94,6 \quad b$ & 134,8 a \\
\hline CT 47 & $14,0 \quad \mathrm{c}$ & $41,3 \quad b$ & 104,5 a & 126,7 a \\
\hline CT 48 & $15,8 \quad b$ & 42,6 a & 118,4 a & 148,9 a \\
\hline CT 49 & $14,7 \mathrm{c}$ & $40,1 \quad b$ & 104,6 a & 129,6 a \\
\hline CT 50 & $15,0 \quad \mathrm{c}$ & 42,5 a & 116,0 a & 149,0 a \\
\hline CT 51 & $14,0 \quad \mathrm{~b}$ & $44,1 \quad a$ & 114,3 a & 144,0 a \\
\hline
\end{tabular}

Remarks: the number of each column followed by the same letter shows no significant difference in the Scott and Knott test of 5\%

Coastal land with DHL $0.21 \mathrm{dSm}-1$ showed generative growth on the variable length of cob significantly different from some of the hybrids tested. Based on Scott and Knott's test, there is a good group of cob lengths in coastal areas, namely CT16, CT17, CT19, CT20, CT21, and CT29 
The largest cob length of $19.3 \mathrm{~cm}$ on CT 16 is even better than the comparative hybrid of $15.6 \mathrm{~cm}$ on BISI 18 hybrids. Cob length is one of the variables used to increase corn crop production, but it must be accompanied by a good cob diameter. The diameter of the cob is affected by the nutrient content and the water available in the soil or the planting media used, the more nutrients the plants need, the greater the diameter of the cob. The largest ear diameter is a hybrid CT 19 of $46.3 \mathrm{~mm}$. CT 19 hybrid has a larger cob diameter than BISI 18 which is used as a comparison with a cob diameter of 42.2 $\mathrm{mm}$.

Based on the results of the skott and knott test analysis of 5\% level of the hybrids tested on the coastal land there is the best hybrid group because it is equivalent to the hybrid comparison of BISI 18. Hybrids CT 17, CT 19, and CT 20. Which have generative growth equivalent to BISI 18 and have a better cob length.

Response of 25 new hybrid maize through nutrient culture there is a group of hybrid maize that has a good response to stress $\mathrm{NaCl}$ with a concentration of $150 \mathrm{mM}$ namely CT18, CT19, СТ22, СТ25, СТ31, СТ33, СТ34, CT40, CT47, and CT50. The hybrid maize group that had high yields in coastal areas were CT 17, CT 19, and CT 20. Both trials had different results, but there were hybrids that were consistent with a good response to $\mathrm{NaCl}$ stress through nutrient culture and coastal land namely CT 19 There are differences in yields through nutrient culture and coastal land because this is influenced by planting media factors. Corn stress in nutrient culture is caused only by $\mathrm{NaCl}$ factor and has $\mathrm{AB}$ Mix nutrition, whereas in coastal areas many factors affect plant growth, namely low C-organic content (1.32\%), P-Bray is very low (3.19 ppm), low K-dd (0.37 me/100g) and $\mathrm{pH} 6.8$. Coastal land is influenced by environmental factors, namely $\mathrm{pH}<8.5$, and is dominated by salts of $\mathrm{Na}, \mathrm{Ca}$ and $\mathrm{Mg}$ in the form of chloride or sulfate which causes low availability of $\mathrm{N}, \mathrm{P}, \mathrm{Mn}, \mathrm{Cu}, \mathrm{Zn}$, and $\mathrm{Fe}$ in the soil, high osmotic pressure, weak water movement, and low soil microbial activity (Tester and Davenport 2003).

\section{CONCLUSIONS AND SUGGESTIONS}

\section{Conclusions}

a. LC50 $\mathrm{NaCl}$ concentration in this study was obtained at $150 \mathrm{mM}$.

b. Based on nutrient cultures with 150 $\mathrm{mM} \mathrm{NaCl}$ stress hybrid CT18, CT19, CT22, CT25, СТ31, СТ33, СТ34, СТ40, CT47, and CT50 have a good response to salinity

c. Based on the results on the coastal land obtained by groups of plants that have good results, namely CT 17, CT 19 and CT 20

\section{Suggestions}

Salinity-tolerant genotype selection is very important to increase maize production in the use of coastal land, so a very precise method is needed more quickly in the determination of tolerant genotypes. From the results of the above research it is necessary to do more research to determine a better method.

\section{REFERENCES}

Asih, E. D, Mukarlina and I. Lovadi. 2015. Tolerance of green mustard plants (Brassica juncea L.) against stress salinity $\mathrm{NaCl}$ salt. Protobiont. 4(1): 203 - 208. 
Central Bureau of Statistics. 2019. Indonesian Statistics. Statistics Center. Jakarta. http:// database.pertanian.go.id Leksim2019/impornegaraasal.p hp (Access September 7, 2019)

Dachlan, A, N. Kasim and A. K. Sari.2013. Salinity resistance test of several corn varieties (Zea mays L.) by Using a $\mathrm{NaCl}$ Selection Agent. Scientific Journal of Biology. 1(1): 9 - 17

Draseffi, D. L, N. Basuki and A. N. Sugiharto. 2015. Characterization of S5 generation inbreed strains in the vegetative phase of corn plants(Zea mays L.). J Plant Production. 3(3): 218-224

Effendy, Respatijarti and B. Waluyo. 2018. Genetic Diversity and Character Heritability of Components of Results and Results of Ciplukan (Physalis sp.).J Agro. 5(1): 30 - 38

Ekowati, D and M. Nasir. 2011. Growth of Corn Plants (Zea Mays L.) Bisi2 Varieties on Reject Sand and Real Sand in Trisik Kulonprogo Beach. J Human and Environmental. 18 (3): 220 - 231

Follett, R. H, L. S. Murphy and R. L. Donahue.1981. Fertilizers and soil amendments. Prentice-Hall. Inc. Englewood, New York

Hoque, M. M.I, Z. Jun and W. Guoying. 2015. Evaluation of Salinity Tolerance in Maize (Zea mays L.) Genotypes at Seedling Stage. J BioSci. Biotechnol. 4(1): 39 - 49

Kurniasari, A. M, Adisyahputra and R. Rosman. 2010. Effect of Drought on $\mathrm{NaCl}$ Salt Soil Against Patchouli Plant Growth. Bul.
Littro. 21(1): 18-27

Latuharhary, A. and T. B. Saputro. 2017. Morphological Response of Corn Plants (Zea mays. L) Bisma and Yellow Srikandi Varieties in High Salinity Stress Conditions. J Science and Art ITS. 6(2): E29 E33

Pranasari, R. A, T. Nurhidayati and K. I. Purwani. 2012. Corn Crop Competition (Zea mays L.) and Teki Grass (Cyperusrotundus) on the Effect of Salt Stress $(\mathrm{NaCl}) . J$ Science and Art ITS. 1(1): E54 E57

Rosmayati, N. Rahmawati, R. P. Astari and F. Wibowo. 2015. Analysis of Vegetative Growth of Soybean Hybridization of Saline Resistant Genotype with Anjasmoro Varieties to Support the Expansion of Planting Areas in Saline Fields. J Tropical Agriculture. 2(2): 132 - 139

Sholihah, N. F. and T. B. Saputro.2016. Maize Response (Zea mays L.) Comparative Varieties Against Salinity Stress $(\mathrm{NaCl})$ In Vitro. J Science and Art. 5(2): 60 - 66

Suwignyo, R. A, R. Hayati, and Mardiyanto. 2010. Corn Tolerance of Salinity with Low Initial Stress Treatment.J. Agrivigor. 10(1): 73 - 83

Tatipata, A and A. Jacob.2013. Remediation of Sandy Land in Waisamu Planted with Local Corn Through Ela Sago Compost Application. J Suboptimal Land. 2(2): 118 - 128

Tavakkoli, E, F. Fatehi, S. Coventry, P. Rangasamy and G. K. M. Donald. 2011. Additive Effects of $\mathrm{Na}^{+}$ and $\mathrm{Cl}^{-}$ions on Barley Growth 
Under Salinity Stress.Journal of

Experimental Botany. 62(6) : 2189

$-2203$

Tester, $\mathrm{M}$ and R. Davenport. 2003. $\mathrm{Na}^{+}$ Tolerance and $\mathrm{Na}^{+}$Transport in Higher Plants.Annals of Botany.
91(5): $503-527$.

Yustiningsih, M and V. U. Sila. 2017. Response of Maize Growth (Zea Mays L.) on Different Salinity Treatments. 1(2): 12 - 19 